\title{
International Metallographic Contest Entries Now Available for Viewing on the IMS Website
}

(c) ASM International 2020

Judging for the annual International Metallographic Contest (IMC) has now been completed. Due to the cancellation of IMAT, attendees missed the opportunity to be able to view all of the contest entries this year, as the posters are normally displayed at the conference. Typically only the winning posters are posted online at the IMS website. However, due to the cancellation of IMAT 2020, the IMC Committee has decided to post all of the posters entered in the contest this year. To view the posters, please go to the IMS website, https ://www.asminternational.org/web/ims, and follow the IMC links to view all of the entered posters. The list of 2020 IMC Winners is available there as well.

Publisher's Note Springer Nature remains neutral with regard to jurisdictional claims in published maps and institutional affiliations. 